\title{
ШИЙТАКЕ (LENTINUS EDODES L) МӨӨГНИЙ ҮЙЛДВЭРИЙН МИЦЕЛЬ ГАРГАН АВСАН СУДАЛГААНЫ ДҮН
}

\author{
Ш.Наранмандах ${ }^{l *}$, Т.Солонгоо \\ ${ }^{1}$ МУИС-ийн Шинжлэх ухааны сургууль, Монгол улс \\ * Цахим шуудан:smandakh@num.edu.mn
}

\section{ХУРААНГУЙ}

СүҮлийн жилүүдэд дэлхийн олон оронд мөөгийг хүнсний болоод эмчилгээний чиглэлээр өргөн хэрэглэх болсон тул мөөгний тариалалт асар хурдаџтай хөгжиж байна. Дэлхий нийтийн хөгжлөө дагаад Монголчууд ч гэсэн мөөгийг ихээр хэрэглэх болсон байна. Иймд өөрийн оронд мөөг тариалж дотоодын хэрэгиээгээ хангах шаардлага урган гарч байна.

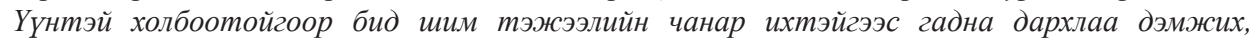
холестрол бууруулах, бактер, вирус, хавдрын эсрэг үйлчилгээтэй шийтаке мөөгний мищелийн иэвэр өсгөврийг сэргээн ургуулж, үйлдвэрийн мицелийг гаргахад тохиромжтой орчин, нөхилийг тогтоох зорилгоор энэхүY судалгааны ажлльг гүйщэтгэв.

Судалгааны хүрээнд шийтаке (Lentinus edodes L) мөөгний иэвэр өсгөврийг сусло агар, төмс-глюкоз агар, сабуро агар гэсэн 3 төрлийн хатуу тэжээлийн орчинд турииж ургуулахад, дээрх орчнуудаас төмс-глюкоз агар хатуу тэжээлийн орчин нь илүҮ тохиромжтой байв. Мөн иэвэр өсгөврийг ургуулах оновчтой температурыг сонгох зорилгоор $+21^{\circ} \mathrm{C},+23^{\circ} \mathrm{C},+25^{\circ} \mathrm{C}-\partial$ ургуулан турииж, $+23^{\circ} \mathrm{C}$ нь хамгийн тохиромжтой болохыг тогтоов. Үүний дараа мөөг тарих үйлдвэрийн мицель гаргах туршилтыг улаан буудай, овьёос, арвай гэсэн 3 төрлийн будаат орчныг сонгон гүйцэтгэсний дүнд улаан буудайт орчин дээр шийтаке мөөгний үйлдвэрийн мицелийг гарган авах нь тохиромжтойг тогтоов.

Түлхүүр үгс: Мицелийн цэвэр өсгөвөр, төмс-глюкоз агар, будаат орчин, оновчтой нөхиөл;

\section{ОРШИЛ}

Орчин үеийн ачаалал ихтэй ажил нь хүнд их стрессийг бий болгож, өвчинд өртөмтгий болгож байна. Ийм нөхцөлд биологийн идэвхт бодистой хүнсний нэмэлт бүтээгдэхүүн ялангуяа мөөг сайн эмчилгээ болдог. Мөөг нь бусад биологийн идэвхт эмчилгээний бодисуудас хор багатай, тун хэмжээ ихдэх гэсэн асуудал байдаггүйгээрээ ялгардаг давуу талтай хүнсний болоод эмчилгээний ач холбогдолтой чухал түүхий эд юм. Мөөг нь хүний биед хялбар шингэдэг уураг, витамин, нүүрс-ус, эрдэс бодис их хэмжээгээр агуулдгаас гадна хоол боловсруулалтанд сайнаар нөлөөлдөг, биеэс хорыг зайлуулах, организмын дархлаа дэмжих зэрэг ихээхэн 
ач холбогдолтой. Азийн олон орнуудад мөөгийг хэдэн мянган жилийн тэртээгээс хэрэглэж ирсэн уламжлалтай. Харин барууны орнуудад сүүлийн 20 жилээс хоол хүнсэндээ хэрэглэх нь ихэсч орчин үед улам бүр өсөн нэмэгдэж байна. Үүнтэй холбоотойгоор дэлхийн улс оронд хүнсний мөөгний тариалалт асар хурдацтай хөгжиж байна. Тухайлбал, таримал мөөгний ургац 1990 онд 3.8 сая тонн, 1994 онд 4.9 сая тонн, 1997 онд 6.2 сая тонн, 2000 онд 7 сая тонн, 2006 онд 14 сая тонн, 2012 онд 26 сая тонн болж өсчээ [1].

Дэлхийн хамгийн их тариалж байгаа таван мөөгний нэг бол Lentinus edodes $L$ буюу шийтаке хэмээх мөөг юм [1]. Хатаасан шийтаке мөөгөнд нүүрс-ус 58$60 \%$, уураг 20-30\%, эслэг 9-10\%, липид $3-4 \%$, эрдэс бодис $4-5 \%$ агуулагддаг $[3,4]$. Түүнийг Япон, Солонгос, Хятад, Вьетнам зэрэг орнуудад эрт үеэс тариалж, хүнсний болоод эмчилгээний зорилгоор хэрэглэж иржээ [8]. Шийтаке мөөг элэг хамгаалах, цусан дахь холестролыг бууруулах, дархлаа дэмжих, ханиад эмчлэх, хавдрын эсрэг маш хүчтэй үйлчлэл үзүүлдгийг тогтоожээ $[3,4]$. Шийтаке мөөгнөөс ялган авсан

\section{МАТЕРИАЛ, АРГА ЗУЙ}

Судалгааны дээж. Lentinula edodes $L$ мөөгний цэвэр өсгөврийг Вьетнам улсын Ургамлын биотехнологийн хүрээлэнгээс 2012 оны 4 сард авчирч хөргөгчинд хадгалж, улирал тутамд сэргээн өсгөвөрлөж байсан.

Мицелийн цэвэр өсгөвөр сэргээн ургуулах. Мицелийн цэвэр өсгөврийг сэргээн ургуулахад дараахь 3 төрлийн хатуу тэжээлт орчныг микробиологийн тэжээлийн орчин бэлтгэх арга зүйн [5] дагуу бэлтгэж хэрэглэв.

1. Төмс-глюкоз агар (ТГА), $\mathrm{pH}=6.0$

2. Сусло агар, $\mathrm{pH}=6.0$

3. Сабуро агар, $\mathrm{pH}=6.0$

Мицель ургуулах температур сонгох. Мицелийн цэвэр өсгөврийг ургуулах лентинан полисахарид нь хорт хавдрын эсийн өсөлтийг саатуулж байсныг анх удаа Чихара нарын эрдэмтэд тогтоосон [2]. Мөн Чеунг, Занг нар лентинан полисахарид нь хүний дархлааны системийг дэмждгийг тогтоогоод байгаа юм [9].

Монгол оронд ч мөн адил мөөгний хэрэгцээ шаардлага өсөн нэмэгдэж байна. Гэтэл Монгол оронд ургадаг мөөгний нөөц хомс бөгөөд үйлдвэрлэлийн түүхий эд болох боломжгүй учир тэдгээрийг зөвхөн тарималжуулснаар л өдрөөс өдөрт өсөн нэмэгдэж байгаа хүн амын хэрэгцээг хангах юм. Иймд дэлхий нийтийн хөгжлөөс хоцролгүй монгол оронд мөөгний үйлдвэрлэлийг хөгжүүлж, өөрийн оронд мөөг тариалж дотоодын хэрэгцээгээ хангах шаардлага гарч байна. Энэхүу нөхцөл байдалтай холбоотойгоор бид өндөр ач холбогдолтой хүнсний мөөгийг монгол оронд нутагшуулан тариалах технологи боловсруулах ажлын эхлэл болгож шийтаке мөөгний мицелийн цэвэр өсгөврийг сэргээн ургуулах болон үйлдвэрийн мицелийг гаргахад тохиромжтой орчин, нөхцлийг тогтоох зорилгоор гүйцэтгэсэн судалгааны ажлын үр дүнг энэхүү өгүүлэлд эмхэтгэв.

тохиромжтой температурыг сонгохдоо $+21^{\circ} \mathrm{C},+23^{\circ} \mathrm{C},+25^{\circ} \mathrm{C}$ гэсэн 3 өөр температурт термостатад 5 хоног ургуулав. Өсгөврийг хатуу тэжээлийн орчин дээр шилжүүлж суулгахад эдийн өсгөвөрлөлтийн аргыг [7] хэрэглэсэн.

Мицелийн иэвэр өсгөврийг будаан дээр ургуулах. УГ туршилтанд улаан буудай, арвай, овъёос гэсэн 3 төрлийн будааг хэрэглэв.

Будаат орчинг бэлтгэх: Будааг хог хаягдлаас нь бүрэн салгаж, шигшүүрээр шигшиж сайтар угааж цэвэрлэнэ. Дараа нь паалантай саванд хийж дээрээс нь будааны түвшинтэй тэнцүү хэмжээний ус хийж, 30 мин зөөлөн гал дээр чанана. Чанасны дараа чийгийн агууламж 65-75\% болтол сэврээж 
хатаана. Хатаасан будааг шохойтой хольж, урьдчилан ариутгаж бэлтгэсэн шилэн саванд савлаж таглаад 1 атм-д $121^{\circ} \mathrm{C}$-д 30 минут ариутгана.

\section{ҮР ДУН, ХЭЛЭЛЦУУЛЭГ}

Шийтаке (Lentinus edodes L) мөөгний мицелийн цэвэр өсгөврийг сэргээн ургуулахад мөөгний өсгөврийг ургуулахад хэрэглэдэг орчнуудаас тохиромжтой байдал болон олдцыг харгалзан үзсэний үндсэн дээр төмс глюкоз агар, сусло агар, сабуро агар гэсэн 3 төрлийн хатуу тэжээлийн орчныг сонгон туршсан. УГ 3 төрлийн хатуу тэжээлт орчин дээр цэвэр өсгөврийг суулгаж, нийт 7 хоногийн хугацаанд ургуулах туршилтыг 3 удаа давтан хийж гүйцэтгэв. Туршилтын дүнгээс харахад эхний 2 хоногт өсгөвөр ижил хэмжээтэй ургасан (Зураг 1А) ба харин 5 дахь хоногоос төмс-глюкоз агар (ТГА) тэжээлт орчин дээр ургалт нөгөө 2 орчинтой харьцуулахад арай илүү ургаж (Зураг 1Б) эхлэсэн. 7 дахь хоногт ТГА орчин дээр Петрийн аягыг бүрэн бүрхэж ургасан (Зураг 1B). Иймд хамгийн тохиромжтой тэжээлт орчныг ТГА гэж сонгов.
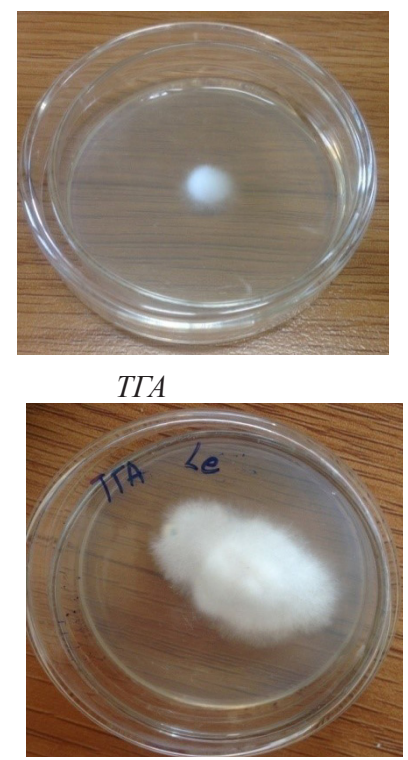

ТГА

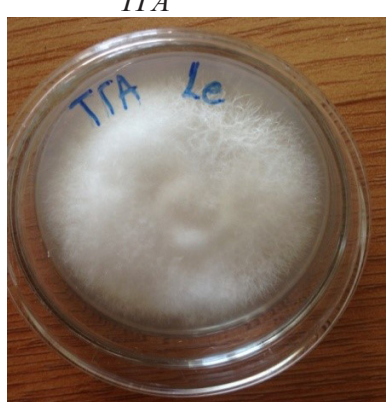

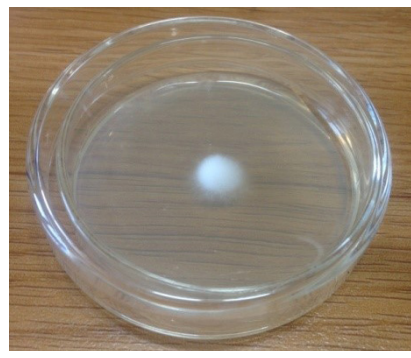

Сусло агар

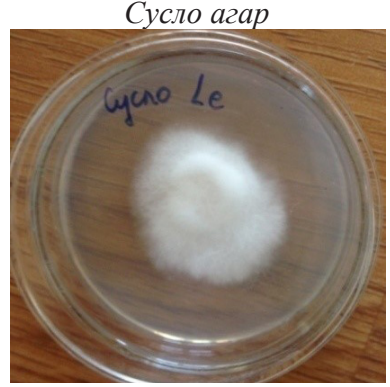

Сусло агар

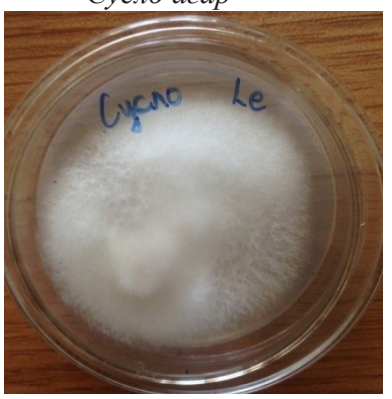

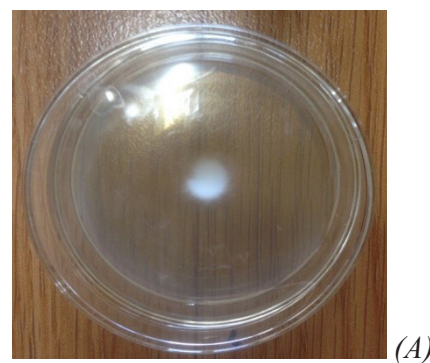

Сабуро агар

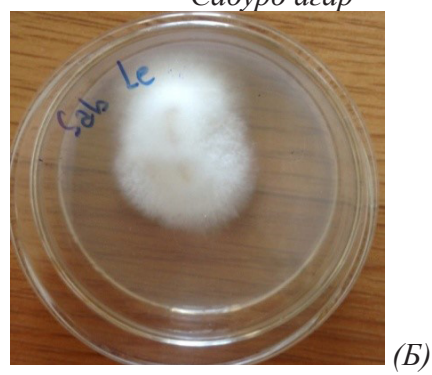

Сабуро агар

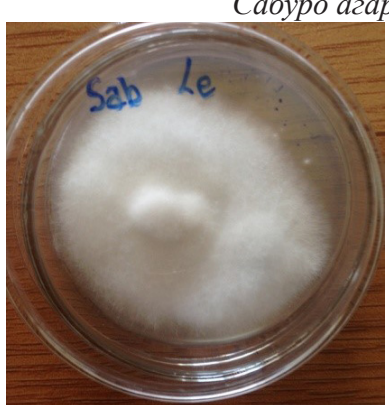

ТГА

Сусло агар

Сабуро агар

(B)

Зураг 1. Хатуу тэжээлийн орчин дээрх шийтаке мөөгний мицелийн ургалт.

(A) 2 хоногийн дараа; (Б) 5 хоногийн дараа; (B) 7 хоногийн дараа -62 - 
Шийтаке мөөгний мицель нь цагаан өнгөтэй, хөвсгөр, нэгэн төрлийн утаслаг байв. Цэвэр өсгөвөр гадны ямар нэгэн мөөгөнцрөөр бохирдоогүй нь микроскопоор харахад тогтоогдсон. Мөн бактераар бохирдсон эсэхийг шалгах зорилгоор махпептоны агар тэжээлт орчин дээр ургуулж шалгахад ямар нэгэн бактер ургаагүй байв.

Шийтаке мөөгний мицелийг ургуулах оновчтой температурыг тогтоох зорилгоор $+21^{\circ} \mathrm{C},+23^{\circ} \mathrm{C},+25^{\circ} \mathrm{C}$ гэсэн 3 өөр температурт термостатад ургуулах туршилтыг 3 удаa давтан гүйцэтгэв. Туршилтын дүнг Хүснэгт 1-д харуулав. Хүснэгт 1-ээс мөөгний мицель $+21^{\circ} \mathrm{C}$-д 7 хоногийн хугацаанд 4см хэмжээтэй ургасан бол $+23^{\circ} \mathrm{C}$-д энэ хугацаанд $5.1 \mathrm{~cm},+25^{\circ} \mathrm{C}$-д энэ хугацаанд $4.5 \mathrm{~cm}$ ургасан байна. $+25^{\circ} \mathrm{C}-$ ын үед ургалт $+23^{\circ} \mathrm{C}$-ын үеийн ургалттай ойролцоо сайн байсан хэдий ч ургах явцад хөлөрч, петрийн аяганы таганд дээр ус үүсч байсан. Иймд дээрх 3 температурыг харьцуулан үзэхэд хамгийн тохиромжтой нь $+23^{\circ} \mathrm{C}$ байв. Мөн энэ туршилтаар шийтаке мөөгний мицелийг ургуулах тохиромжтой тэжээлт орчин ТГА болох нь (Хүснэгт 1-ээс харахад) дахин батлагдлаа. Мөөгний мицель нь $+23^{\circ} \mathrm{C}$-ын үед сусло агар дээр сайн ургаж байв. Иймд мицелийн өсгөвөрлөлтөнд сусло агарыг бас хэрэглэх боломжтой юм.

ХУснэгт 1. Шийтаке мөөгний мицелийг ургуулах тохиромжтой температурыг сонгох туриилтын $\partial{ }^{H}$

\begin{tabular}{|c|c|c|c|}
\hline \multirow{3}{*}{ Тэжээлт орчин } & \multicolumn{3}{|c|}{ Өсгөвөрлөлтийн температур, ${ }^{\circ} \mathrm{C}$} \\
\hline & $+21^{\circ} \mathrm{C}$ & $+23^{\circ} \mathrm{C}$ & $+25^{\circ} \mathrm{C}$ \\
\hline & \multicolumn{3}{|c|}{ Мицелийн ургалт 7 хоногийн туршид } \\
\hline ТГА & $\begin{array}{c}\varnothing=4-4.2 \\
/++/\end{array}$ & $\begin{array}{c}\varnothing=4.9-5.1 \\
/+++/\end{array}$ & $\begin{array}{c}\varnothing=4.5 \\
/++/\end{array}$ \\
\hline Сусло агар & $\begin{array}{c}\emptyset=3.5-3.8 \\
1++/\end{array}$ & $\begin{array}{c}\varnothing=4.8-5.0 \\
/+++/\end{array}$ & $\begin{array}{c}\varnothing=4.6-4.9 \\
1++/\end{array}$ \\
\hline Сабуро агар & $\begin{array}{c}\varnothing=2.5-2.8 \\
/+/\end{array}$ & $\begin{array}{c}\varnothing=3.5-3.8 \\
1++/\end{array}$ & $\begin{array}{c}\varnothing=3-3.5 \\
/++/\end{array}$ \\
\hline
\end{tabular}

Тайлбар: Ø- ургалтын диаметр, см

,,++++++ ургалтын эрчим

Шийтаке мөөгний өсгөврийг ургуулах тохиромжтой хатуу тэжээлт орчин болон оновчтой температурыг тогтоосны дараагаар үйлдвэрийн мицелийг гаргах тохиромжтой будаат орчинг тогтоох туршилтыг явуулав. Энэ зорилгоор хатуу тэжээлийн орчин дээр ургуулсан мицелийг овъёос, улаан буудай, арвай гэсэн 3 төрлийн будаат орчныг сонгон туршив. Туршилтыг
4-5 удаа давтан гүйцэтгэсэн ба туршилтын дүнгүүд адил байсан. Иймд нэг удаагийн туршилтын үеийн зургийг төлөөлүүлэн харуулав. Бэлтгэсэн орчин дээр эхний 2 хоногт мицель ургаж эхлээгүй (Зураг 2А), харин 5 дахь хоногоос эхлэн сайн ургаж, 10 дахь хоногт ялгаа нь эрс ажиглагдав. (Зураг 2Б). 

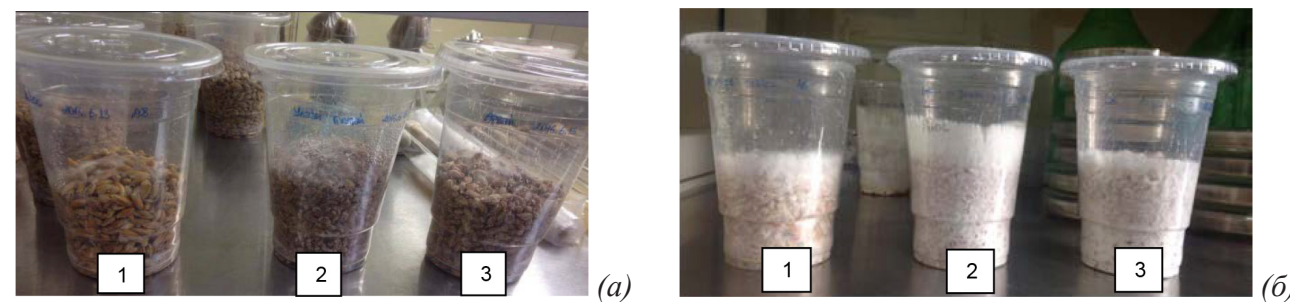

Зураг 2. Будаат орчин дээрх мицелийн ургалт. (А) 2 хоногийн дараа; (Б) 10 хоногийн дараа 1. Овъёос 2. Улаан буудай 3. Арвай

Шийтаке мөөгний мицелийн ургалтын эрчмийг 4 удаагийн туршилтын дундаж утгыг ашиглан График 1-ээр харуулав. График 1-ээс харахад мөөгний мицель овъёос дээр 6 хоногт $6 \mathrm{~cm}, 10$ хоногт 9 см нүүж ургасан бол улаан буудай дээр 6 хоногт $16 \mathrm{~cm}, 10$ хоногт $26 \mathrm{~cm}$ ургасан байна.
Туршилтын дүнгээс харахад мөөгний мицелийн ургалт улаан буудайн дээр хамгийн сайн байсан тул шийтаке мөөгний үйлдвэрийн мицель гарган авахдаа улаан буудайн дээр ургуулах нь зүйтэй хэмээн үзэж байна.

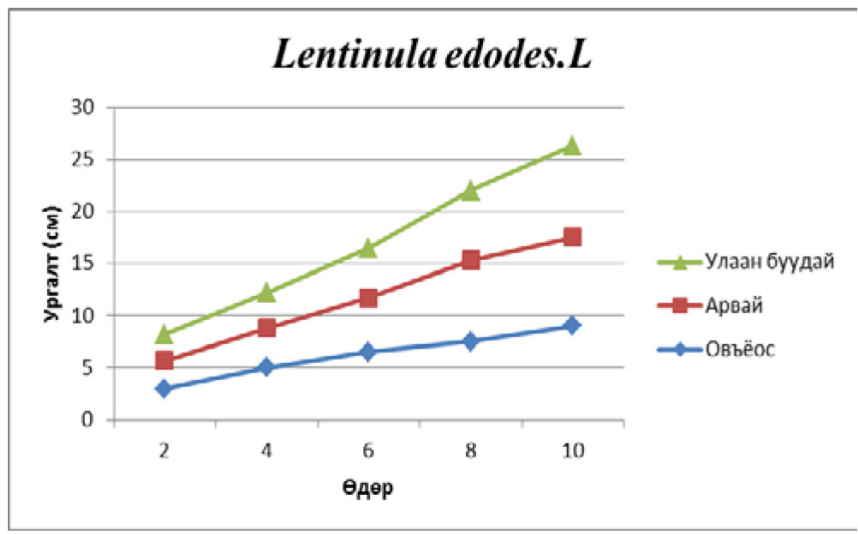

График 1. Будаат орчин дээрх мищелийн ургалт

\section{ДҮГНЭЛТ}

Шийтаке Lentinula edodes L мөөгний мицелийн цэвэр өсгөврийг төмс глюкоз агар, сусло агар, сабуро агар гэсэн 3 төрлийн хатуу тэжээлийн орчин дээр ургуулж туршихад мөөгний мицель ТГА орчин дээр 7 хоногт Петрийн аягыг бүрэн бүрхэж ургаж байсан тул ТГА орчин нь шийтаке мөөгний мицель ургуулах хамгийн тохиромжтой хатуу тэжээлт орчин гэж үзэв.

Шийтаке Lentinula edodes L мөөгний мицелийн цэвэр өсгөврийг ургуулах оновчтой температурыг тогтоох зорилгоор
$+21{ }^{\circ} \mathrm{C}, \quad+23^{\circ} \mathrm{C}, \quad+25^{\circ} \mathrm{C} \quad$ гэсэн 3 өөр температурт ургуулах туршилт явуулахад $+23^{\circ} \mathrm{C}$-ын үед шийтаке мөөгний мицел бусад температурын үеэс хамгийн сайн ургасан буюу 7 хоногийн хугацаанд 5.1 см ургаж байв. ИйнхүҮ шийтаке мөөгний мицелийг ургуулах оновчтой температур $+23^{\circ} \mathrm{C}$ болохыг тогтоов.

Шийтаке Lentinula edodes L мөөгний үйлдвэрийн мицель гаргах будаат орчныг сонгох туршилтыг улаан буудай, арвай, овьёос гэсэн 3 өөр орчин дээр явуулсны дүнд шийтаке мөөгний мицель улаан буудай 
дээр хамгийн сайн ургадгийг тогтоов. Иймд шийтаке мөөгний үйлдвэрийн мицель гарган авахдаа улаан буудайг хэрэглэх нь зүйтэй гэж үзэв.

Энэхүу судалгааны дүнд шийтаке мөөгийг монгол орны түүхий эдийг ашиглан нутагшуулан тариалах технологи бий болгох ажлын эхлэл амжилттай хийгдэж, цаашид тариалах ажил амжилттай хийгдэх боломж бүрдсэн хэмээн үзэж байна.

\section{НОМ ЗҮЙ}

[1] Chang, S.T. World production of cultivated edible and medicinal mushrooms in 1997 with emphasis on Lentinus edodes (Berk.) Sing. In China. Int. J. Med. Mushr. 1999, 389409.

[2] Chihara G, Hamuro J, Maeda Y, Arai Y,Fukuoka F. Fractionation and purification of the polysaccharides with marked antitumour activity, especially lentinan, from Lentinus edodes (Berk.) Sing, an edible mushroom. Cancer Res 30. 1970, 2776-2781.

[3] Cheung, P.C. Mushrooms as functional food. Wiley, New York.2008,

[4] Mizuno, Shiitake, Lentinus edodes. Functional properties for medicinal and food purposes. Food Rev. Int. 1995 (11) 7-12.

[5] Quimio.T.H., Chang.S.T., Royse.D.J. "Technical guidelines for mushroom growing in the tropics" 1990, 26-28.

[6] Singer, R., Harris, B. Mushrooms and Truffles. Botany, Cultivation, and Utilization, 2nd Ed.; Koeltz Sci. Books: Koenigstein, 1987.

[7] Stamets, P. Growing Gourmet and Medicinal Mushrooms, 3rd Ed., Ten Speed Press: CA, USA, 2000.

[8] Wasser, S.P. Weis, A.L. Medicinal Mushrooms. Lentinus edodes (Berk.) Singer; Nevo, E., Ed.; Peledfus Publ. House: Haifa, Israel, 1997,95.

[9] Zhang, Y.L., Wang, X.,Zhang,L., Cheung,PCK.Advances in lentinan. Isolation, structure, chain conformation and bioactivities. Food Hydrocolloid 25,2011,196-206. 


\title{
STUDY ON SPAWN TECHNOLOGY OF THE SHIITAKE (LENTINUS EDODES L)
}

\author{
Sh.Naranmandakh ${ }^{1 *}$, T.Solongoo ${ }^{1}$ \\ ${ }^{1}$ National University of Mongolia, School of Arts and Sciences \\ * corresponding author e-mail: smandakh@num.edu.mn
}

\begin{abstract}
Last years mushrooms are increasingly becoming a vital component of the human diet throughout the world. Therefore, the world production of cultivated edible mushrooms has been intensively increased. Also Mongolians have been to use mushrooms widely, following world development. It's necessary to cultivate mushrooms in Mongolia for supply our domestic demand. A main purpose of our research was to establish a spawn technology of shiitake mushroom using Mongolian raw materials.

Shiitake (Lentinus edodes L) has a good nutritive value and immunomodulating, antiviral, antibacterial, anticancer, cholesterol lowering effects. Therefore, we have chosen this mushroom for the research. Within the research, experiment on 3 types of solid culture medium whose are potato dextrose agar, sabouraud's agar and syslo agar were conducted. Potato dextrose agar was more convenient to cultivate the shiitake's mycelia. For finding out the optimal temperature, were evaluated at 3 different temperatures $\left(+21^{\circ} \mathrm{C},+23^{\circ} \mathrm{C}\right.$ and $\left.+25^{\circ} \mathrm{C}\right)$. The optimal temperature was $+23^{\circ} \mathrm{C}$. As a results of the experiment have established that the shiitake's mycelia is growing very good in potato dextrose agar at $+23^{\circ} \mathrm{C}$. In this condition the shiitake's mycelia have grown 51 $\mathrm{mm}$ during one week. For finding out the best grain culture medium, were used 3 different grains whose are wheat, oats and barley. As a result of these studies, have established that the best grain culture medium for obtaining a second spawn of shiitake is a wheat.
\end{abstract}

Keywords: mycelial pure culture, potato dextrose agar, grain culture medium, optimal condition; 